\title{
ADMINISTRASI PENDIDIK DAN TENAGA KEPENDIDIKAN
}

\author{
Nofita Sari \\ E-mail \\ nofitasari91199@gmail.com
}

\begin{abstract}
ABSTRAK
Administrasi pendidik dan tenaga kependidikan sangat penting dalam sistem pendidikan dimana proses pembelajaran dapat berjalan dengan lancar sebagaimana mestinya. Administrasi pendidik dan tenaga kependidikan merupakan salah satu sumber daya untuk mencapai tujuan pendidik secara produktif, sebagaimana adanya proses administrasi, kesejahteraan ptk, pembinaan pengembangan, eveluasi kerja, kenaikan pangkat dan pemberhentian, serta peran guru dalam administrasi pendidik dan tenaga kependidikan. Dengan adanya hal tersebut maka pendidikan dapat berjalan menuju pendidikan yang bermutu dan berjalan dengan baik.
\end{abstract}

Kata kunci: Administrasi, Pendidik dan Tenaga Kependidikan

\section{PENDAHULUAN}

Administrasi pendidik dan tenaga kependidikan merupakan salah satu hal penting yang terdapat dalam sistem pendidikan agar proses pembelajaran dapat berjalan secara semestinya. Tenaga pendidik dan kependidikan ini mengambil peranan yang sangat penting terutama dalam pembentukan karakter bangsa. dengan pengembangan kepribadian dan nilai luhur bangsa.

Jika dilihat dari segi proses pembelajaran peranan pendidik sangat penting terhadap proses pembelajaran meskipun sekarang teknologi yang ada sudah sedemikian canggih, hal ini disebabkan karena adanya hal-hal dalam proses pendidikan dan proses pembelajaran yang tidak dapat digantikan oleh teknologi.

Oleh sebab itu fungsi mereka tidak akan bisa seluruhnya dihilangkan sebagai pendidik dan pengajar bagi peserta didiknya. Begitu pun dengan tenaga kependidikan, peranan mereka juga sudah dapat digantikan dengan teknologi seutuhnya untuk menunjang proses berlangsungnya pendidikan pada satuan pendidikan.

\section{TEORI DAN PEMBAHASAN}

A. Proses administrasi pendidikan PTK

- Pengadaan tenaga kependidikan Pengadaan tenaga personil adalah proses kegiatan untuk mengisi formasi yang 
kosong. Perlu diketahui

bahwa lowongan suatu

formasi, disamping

disebabkan karena

pengembangan lembaga

dengan menambah jabatan-

jabatan baru juga

disebabkan adanya personil

lembaga yang

berhenti(Afriansyah. 2019)

- Penempatan

Merupakan tindakan

pengaturan atau seseorang untuk menempati posisi atau jabatan.

- Orientasi

Merupakan upaya
memperkenalkan seorang
tenaga kependidikan yang
baru terhadap situasi dan
kondisi pekerjaan dan
jabatannya.

B. Kesejahteraan Ptk

a. Gaji, yang dimaksud dengan gaji adalah ha yang diterima oleh guru atau dosen atas pekerjaannya

dari

penyelenggaraan pendidikan atau satuan pendidikan dalam bentuk financial secara berkala sesuai peraturan perundangundangan.

b. Tunjangan, diberikan kepada guru yang telah memiliki sertifikat pendidik yang

diangkat oelh

penyelenggarakan pendidikan

dan satuan pendidikan yang

diselenggaraan oelh

masyarakat.

c. Penghargaan, pemerintah memberikan penghargaan di institusi pendidikan terhadap guru, dosen,kepala seluruh pendidikan yang berprestasi.

d. Cuti ptk, cuti tahunan, cuti besar, cuti sakit, cuti karena alasan penting.

Pengertian Administrasi

Pendidik dan Tenaga

Kependidikan

Engkoswara

mengemukakan administrasi pendidikan dalam arti yang seluas-luasnya adalah "suatu ilmu yang mempelajari penataan sumber daya untuk mencapai tujuan pendidikan secara produktif.

Pengertian Administrasi Pendidik dan Tenaga Kependidikan (PTK)

Administrasi dalam pengertian secara harfiah, kata "adminitstrasi" berasal dari bahasa latin yang terdiri dari kata ad dan ministrare. Kata ad mempunyai arti sama dengan kata to dalam bahasa inggris yang berarti "ke" atau 
"kepada". Dan kata ministrare sama dengan kata to serve atau to conduct yang berarti melayani, membantu dan mengarahkan. Dalam bahasa inggris to administer berarti pula “ mengatur, memelihara dan mengarahkan”.

C. Pembinaan dan Pengambangan Pendidik dan Tenaga Kependidikan Strategi pengembangan tenaga pendidik dan kependidikan meliputi proses dan langkah-langkah yang cukup kompleks meliputi:

1. Analisis kinerja

2. Analisis kebutuhan

3. Analisis sumber daya

D. KenaikanPangkat pemberhentian PTK

1. Kenaikan Pangkat $\begin{array}{rrr}\text { Setiap } & \text { personil berhak } \\ \text { memperoleh } & \text { kenaikan pangkat }\end{array}$ apabila telah memenuhi persyaratan yang diperlukan untuk kenaikan pangkat itu. Kenaikan pangkat bukan saja sebagai hak yang dapat diterima oleh setiap personil, tetapi juga sekaligus sebagai pemberian penghargaan kepada personil yang bersangkutan atas jerih payah pengabdiannya. Karena itulah kenaikan pangkat dapat mempunyai nilai motivatif yang tinggi.

\section{E. Pemberhentian PTK}

Pengertian Pemberhentian Pegawai Pemberhentian Pegawai Negeri Sipil adalah pemberhentian yang menyebabkan yang bersangkutan tidak lagi berkedudukan sebagai Pegawai Negeri Sipil.Pemberhentian dari jabatan negeri adalah pemberhentian yang menyebabkan yang bersangkutan tidak lagi bekerja pada satuan organisasi Negara, tetapi masih berkedudukan sebagai Pegawai Negeri Sipil.

\section{F. Evaluasi Kinerja}

Evaluasi dan Penilaian Tenaga Pendidik dan Kependidikan merupakan suatu proses penilaian atau pembinaan seorang pendidik. Evaluasi sendiri mempunyai arti secara singkat yaitu sebagai proses mengumpulkan informasi untuk mengetahui pencapaian belajar kelas atau kelompok. Hasil evaluasi diharapkan dapat mendorong guru untuk mengajar lebih baik dan mendorong peserta didik untuk belajar lebih baik. Jadi, evaluasi memberikan informasi bagi kelas dan guru untuk meningkatkan kualitas proses belajar mengajar.

G. Peran Guru dalam Administrasi Pendidik dan Tenaga Kependidikan 
Menurut Oteng

Sutrisna

(1986), (dalam Abin Syamsudin

DAN Nandang Budiman, 2005 :

2.5), administrasi adalah suatu kegiatan atau usaha untuk membantu melayani, mengarahkan, atau mengatur semua kegiatan dalam mencapai suatu tujuan.

Adapun peranan guru dalam Administrasi pendidik dan tenaga kependidikan yaitu :

1. Membuat buku induk pegawai

2. Mempersiapkan usul kenaikan pangkat pegawai negeri, prajabatan, kerpeg, cuti degan pegawai, dll.

3. Membuat inventarisasi semua file kepegawaian, baik kepada sekolah, guru maupun tata administrasi.

4. Membuat laporan rutin kepegawaian harian, mingguan, bulanan dan tahunan.

5. Membuat laporan data sekolah dan pegawai

6. Mencatat tenaga pendidik yang akan mengikuti penataran.

7. Mempersiapkan surat keputusan kepada sekolah tentang proses KBM, surat tugas, surat kuasa,

\section{KESIMPULAN}

Sebagaimana kita ketahui bahwasanya administrasi pendidik dan tenaga kependidikan sangatlah diperlukan dalam pendidikan. Karna memiliki peranan yang sangat penting dalam proses pembelajaran agar dapat berjalan dengan sebaik-baiknya.

Daftar Pustaka

Afriansyah, H. 2019. Administrasi pendidikan dan tenaga kependidikan . padang:osf.io. https://doi.org/10.17605/OSF.IO /TZ4VF

Engkoswara.1987. dasar-dasar administrasi pendidikan. Jakarta: Depdikbut Ditjen Dikti Proyek Pengembangan lembaga pendidikan dan tenaga kependidikan.

Sutisna Oteng. 2004. Administrasi pendidikan: Dasar Teori dan Praktek Profesional. Bandung : Andi Offset 